\title{
Editorial
}

\section{Plastic surgery museum}

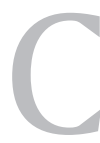

an you tell me why we have been conditioned to think small, simplify, not to be greedy and to overall expect less and demand less from life. We've been taught that we should be happy and thankful with what we have and that there are many others less fortunate than ourselves. While I am prepared to feel sorry for them, I am not prepared to have an anaemic wish list. And I am most certainly not ashamed of aiming for the moon. Hence, here is my next big (and expensive) idea.

Why not have an Association of Plastic Surgeons of India (APSI) Plastic Surgery Museum like the Hunterian Museum of the Royal College of Surgeons? Why not designate an official APSI Historian, who will double up as the museum curator? International Federation of Plastic, Reconstructive \& Aesthetic Surgeons (IPRAS) has an official historian, the profoundly knowledgeable Dr. Riccardo Mazzola from Italy. Why shouldn't we have one? A museum is defined as 'a non-profit making permanent institution, in the service of the society and its development and open to the public, which acquires, conserves, communicates and exhibits, researches for the purpose of study, education and enjoyment, material evidence of men and his environment.' This declaration was made in Copenhagen in 1974 in the $10^{\text {th }}$ General Assembly of the International Council of Museums, and I feel we can abide by it in both letter and spirit.

India, with its rich heritage of Surgery, thanks to the exploits of Dhanvantri, Kshipati Divodasa, Sushrutha, Aupadhenava, Aurabhra, Paushakalavata, Gopurarakshita and Bhoja, is the most natural home to a Plastic Surgery Museum. My predecessor Prof. Mukund Thatte has carried out some research on this subject to make a

\begin{tabular}{|l|l|}
\hline \multicolumn{2}{|c|}{ Access this article online } \\
\hline Quick Response Code: & Website: \\
\hline & www.ijps.org \\
\cline { 2 - 2 } & Dol: \\
\hline
\end{tabular}

movie on Sushruta, which was shown in the IPRAS New Delhi meeting. The surgeons from Varanasi, by virtue of their close proximity to the archives in Banaras Hindu University (B.H.U.) can always add to it. Let us plan it really big so that the generations to come can be proud of our vision and foresight!

Many teaching institutions in our country have such museums, and in our own King George's Medical College in Lucknow, we have excellent Anatomy, Pathology and Forensic Medicine museums. Our plastic surgery department too has a small museum, but at a national level we need to pool our resources and come up with a grand plan! So long as we do not have a space to house our exhibits let us start collecting them in a "Virtual Museum" and designate a Museum curator with proper knowledge, skill and interest. We will only accept donations and give due credit to the donor, but we will not buy any exhibit. Let us send him all the interesting photographs of past APSI and other sub-speciality meetings, videos of APSI accredited workshops, texts of all the Gillies, Sushruta and Godrej Orations, all IJPS journals till date, photographs and videos of all inventions/patents/new flaps/new procedures and anything else you feel demands a place in history. Rarity should not the only consideration; their value, historical association, connection with some important discoveries, links in the development of our speciality, etc., should also be taken into account. Whatever is the collection, educating the public of today and students of tomorrow through various educational activities will be one of the primary functions of the Museum.

What else will this Museum house? Besides the photo/ biography of past stalwarts, it can house inventions/ patents, videos of unique procedures, photos of landmark events, History of Association of Plastic Surgeons of India and all its meetings, CMEs and workshops. I suggest that we send out letters to all the teaching units in India as well as large centres of repute and ask them to compile data including but not necessarily restricted to the following

- Cover page of key articles published by their unit with available hyperlinks

Indian Journal of Plastic Surgery January-April 2013 Vol 46 Issue 1 
- History of the department with notable landmarks

- Any original or novel innovations/patents

- Key visitors to the department

- Archived photographs.

All these can be uploaded on the museum site and categorized - not department wise but more on a time line basis starting from 1950s. An enthusiastic task force should be formed, which should include representatives of all levels of seniority, from all parts of the country, of both sexes and a person be nominated to head this team. This team should be given 1 year to think individually, discuss collectively and come up with a grand plan! This can be done.

The Hunterian Museum houses one of the oldest collections of anatomical, pathological and zoological specimens and is a result of labour and passion of many. They also have wax teaching models, surgical and dental instruments as well as paintings, drawings and sculptures. The collections have been brought together over four centuries by a cast of colourful characters including the surgeon and anatomist John Hunter (1728-1793). Established in 1813, the museum completes 200 years this year. Reopened in 2005 after a $\leq 3.2$ million refurbishment, permanent displays and a changing programme of temporary exhibitions encourage visitors to explore the science and art of surgery. However, it too was started 1 day, and it sure started from scratch! That is where we are today. Visit to this museum is a huge learning experience, and we in APSI need to do something along these lines for posterity.

All museums are not such large and massive establishments. A quick Google search revealed a host of such archives in the United Kingdom alone

- Anaesthesia heritage centre

- Bethlem royal hospital archives and museum

- BDA dental museum

- British optical association museum

- British red cross museum and archives

- Florence nightingale museum

- Freud museum

- Great ormond street hospital museum

- Old operating theatre and herb garret

- Royal college of physicians museum

- Royal London hospital museum and archives

- Royal pharmaceutical society museum.

Our Association was started by a group of teacher blessed with natural nobility, culture, compassion, tolerance and truth. We feel that these qualities need to be treasured and renewed in the generations to come and only history, documented today, will pass them on. With every passing year, our Association of Plastic Surgeons of India is losing some of its stalwarts and torch bearers of yesteryears. We believe we draw inspiration from history. It is through honouring the people, places and events of history that we remember those who came before us and who contributed something meaningful that resulted in making our present world a better place to live in. We also believe that when young people look at our past and learn about a person, an era or a historical event that person represents, an alchemic 'passing of knowledge' transpires. When present and future generations are inspired by these innovative and 'ahead of their times' individuals and their legacies, an enhanced sense of community pride emerges, bringing with it positive energy, education and a better today with a promise of an even better tomorrow. It would be a pity if after 100 years Plastic Surgeons forget about the likes of Prof. N.H. Antia, Prof. C. Balakrishnan, Prof. Murari Mohan Mukherjee, Prof. R.N. Sharma and Prof. B.B. Joshi. A museum of Plastic Surgery will be an ideal tribute to them and a fitting present for the future generation. I trust there will be no shortage of funds for this noble purpose.

Many overseas surgeons have from time to time helped our Association and its members by coming to our conferences training our trainees both here in India as well as in their own overseas units. The museum needs to acknowledge them, the likes of Mr. Ian Jackson, Mr. Ian McGregor, Mr. A.C.H. Watson, Mr. W.A. Morrison, Nr. David David and many others! A gallery should be dedicated to the true stalwarts of Plastic Surgery - the likes of Harold Gillis, Eric Peet, T.P. Killner, Ralph Millard, Paul Tessier, Robert Goldwyn and Fernando Oritz Monastario, for without them Plastic Surgery would have been infinitely poorer. There should be galleries for sub-specialities depicting how they came into existence and then bloomed and flourished both in India and elsewhere.

A Plastic Surgery Museum will thus be a place of learning. Learning in museums generally involves a visitor attending to an object, a display, label, person, element or some mental construct of these. Museum learning has long been examined in relation to attracting power and loading power of exhibits in museums. The information thus collected by the visitors is stored in the brain and remains there over a period. This information a visitor receives during a museum visit tends to bear a "contextual 
map'. Any information obtained during the museum visit will likely include social related, attitude related, cognitive related and sensory related association. These associations will become embedded in the memory of the visitor altogether with the result that anyone facet of these experiences can facilitate the recall of the entire experience. Thus, Museums are rather a source of intellectual stimulation.

'Museum, the temple of the Muses,' the very word conveys to one a sense of a place of learning and study, The element of the sacred temple and that of an educational institution had mingled in the Greek Schools of Philosophy of Pythagoras in the South Italy and Platos
Academy at Sicily, Italy, where the study of philosophy was regarded as services to the Muses. Thus, the temples of Muses were the temple of learning from the very inception of their evolution. Let us in APSI, through this rather ambitious project, chart our own evolution and enshrine them for posterity. Together if, we can shape the future of our speciality, we can surely shape this project.

\section{Surajit Bhattacharya}

Editor

Indian Journal of Plastic Surgery E-mail: surajitbh@yahoo.co.in

How to cite this article: Bhattacharya S. Plastic surgery museum. Indian J Plast Surg 2013;46:1-3.

\section{“QUICK RESPONSE CODE” LINK FOR FULL TEXT ARTICLES}

The journal issue has a unique new feature for reaching to the journal's website without typing a single letter. Each article on its first page has a "Quick Response Code". Using any mobile or other hand-held device with camera and GPRS/other internet source, one can reach to the full text of that particular article on the journal's website. Start a QR-code reading software (see list of free applications from http://tinyurl.com/yzlh2tc) and point the camera to the QR-code printed in the journal. It will automatically take you to the HTML full text of that article. One can also use a desktop or laptop with web camera for similar functionality. See http://tinyurl.com/2bw7fn3 or http://tinyurl.com/3ysr3me for the free applications. 